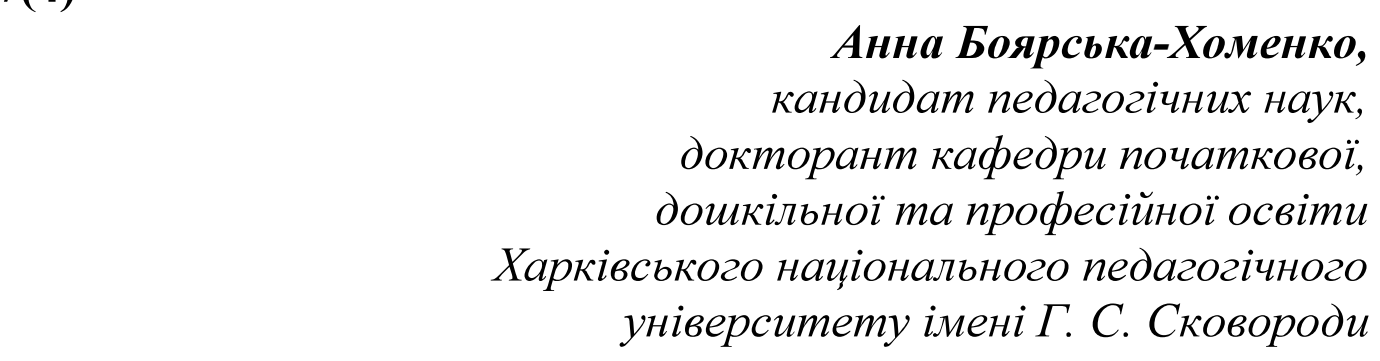

\title{
РЕАЛІЗАЦІЯ УКРАЇНОЮ ПРОГРАМ ЮНЕСКО ЩОДО ОСВІТИ ДОРОСЛИХ
}

У статті проаналізовано міжнародні нормативно-правові акти ЮНЕСКО щодо освіти дорослих та визначено можливості їх реалізації в Україні. Наголошено, щзо міжнародна організація ЮНЕСКО сприяє становленню та розвитку освіти дорослих в усьому світі, у тому числі в Україні. Метою співробітництва Украӥни з ЮНЕСКО є зміцнення інтелектуального потенціалу країни та залучення його до загальносвітових процесів в гуманітарній сфері, а також використання в національних інтересах можливостей $i$ ресурсів ЮНЕСКО та міжнародного досвіду співпрацуі у галузях компетенції иүієї Організації. Міжнародні програми, проекти та рекомендації сприяють становленню нормативно-законодавчої бази України щуодо освіти дорослих, розииренню мережі навчальних закладів для дорослих, популяризачії неформальної та інформальної освіти, розробиі принципів, форм та методів сучасної освіти дорослого населення.

Ключові слова: освіта дорослих, освіта впродовж життя, освітні програми ЮНЕСКО, формальна освіта, неформальна освіта, інформальна освіта, Україна.

In the article UNESCO international legal acts on adult education are analyzed. They are: The Lifelong Learning Program: education and training opportunities for all (2011), The Hamburg declaration (1997), The world of Education Today and Tomorrow (1972), The Sustainable Development Goals Report 2017, Program and budget 2016-2017. The possibility of their realization in Ukraine is determined. It is noted that the UNESCO international organization (United Nations Educational, Scientific and Cultural Organization) promotes the organization of adult education in all the world, including Ukraine. The aim of Ukrainian cooperation with the UNESCO is to strengthen the country's intelligent potential and engage it in the global processes in the humanitarian field, as well as the use of the capabilities and resources of the UNESCO and the international experience of cooperation in the fields of 
competence of this organization in the national interest. It was emphasized that the International conferences, the UNESCO University Departments Program (UNITWIN), the Grundtvig Program were had a significant impact on the development of adult education and the organization of lifelong learning in Ukraine. On the basis of the analysis and generalization of the official legislative and regulatory acts, documents and reports of the UN, UNESCO and Ukraine it has been established that international programs, projects and recommendations contribute to the formation of the Ukrainian legislative and regulatory framework as for adult education, to the expansion of the network of educational institutions for adults, to the promotion of non-formal and informal education, to the development of the principles, forms and methods of adult education. In particular, the international UNESCO conferences on adult education, the UNITWIN/UNESCO Chairs Programme, the Grundtvig Programme have had the most positive influence on the development of the system of adult education in Ukraine. The difficulty in the implementation of UNESCO adult education programs in Ukraine exist. They are: awareness of adults about the possibility of participating in educational programs, stereotypical fears about adult education, a small amount of funding for educational projects, absence of special legislation in the field of adult education.

Key words: adult education; lifelong learning; the UNESCO educational programmes, formal education, non-formal and informal education.

Сучасні стратегії прогресу базуються на принципах загальносвітового розвитку людського потенціалу, відповідно до цього роль освіти постійно зростає. Глобалізаційні процеси, основою яких $\epsilon$ міжнародна інтеграція, сприяють розробці загальної стратегії у сфері освіти дорослих, а також політики ії реалізації. На сьогоднішній день освіта дорослих визначає успішний економічний, соціальний, політичний та екологічний розвиток суспільства, сприяє досягненню цілей $\mathrm{OOH}$ в рамках програми «Освіта 2030» [16]. Організація та розвиток безперервної освіти забезпечує досягнення цілей Лісабонської концепції для сталого, систематичного та інклюзивного зростання.

Освіта дорослих займає важливу нішу в системі освіти країн Свропи. Процеси глобалізації у сфері освіти, розширення кордонів Свропейського Союзу, прогресивна міграційна та інтеграційна політика європейських країн дали потужний поштовх для розвитку освіти впродовж життя. 3 огляду на вищезазначене, закономірною $є$ зумовлена потреба в отриманні та удосконаленні освіти дорослим населенням країн Свропи 3 метою набуття можливості займати гідне місце в суспільстві.

Детермінанти розвитку сучасного суспільства визначають умови, що стимулюють активну розробку питань освіти дорослих, переосмислення 
базових орієнтирів освіти: для сьогодення характерні надзвичайно швидкі процеси застарівання знань та, відповідно, необхідність їх постійного оновлення. Унаслідок таких процесів виникає потреба в отриманні нових знань і нових компетенцій вже у процесі професійної діяльності дорослих людей. Так, знання, отримані в університеті, вже не можуть залишатися незмінним багажем, який ефективно забезпечує соціальну та професійну адаптацію протягом всього життя.

У світлі останніх реформ в освітній галузі України та прийняття Закону «Про освіту» (2017р.) [11], уряд країни ініціював розроблення проекту Закону України «Про освіту дорослих». Тому, як ніколи раніше, актуальним стає вивчення питань реалізації програм ЮНЕСКО щодо освіти дорослих, їхне нормативно-правове регулювання, визначення принципів, форм та методів організації освітнього процесу, засобів залучення широкого кола дорослих людей до навчання впродовж життя.

Виходячи із зазначеного вище, можна узагальнити умови, які стимулюють активну розробку питань освіти дорослих в Україні та у світі. Це:

- прийняття міжнародних нормативно-правових актів щодо освіти дорослих;

- глобалізація світового освітнього простору;

- позитивний імідж освіти дорослих;

- визнання педагогічним співтовариством пріоритету гуманістичної освіти;

- концепція збалансованої освітньої політики;

- формування демократичних освітніх програм.

Для вирішення поставлених перед суспільством завдань розвитку освіти необхідно забезпечити дорослих людей інструментарієм для розуміння соціальних, економічних, політичних та глобалізаційних процесів; уміннями змінювати навколишній світ, жити у сучасному світі, який постійно трансформується, брати участь у всіх видах людської діяльності, співпрацювати 3 іншими людьми. Нагальною є проблема надання дорослим людям можливості навчитися жити у сьогоденні [13].

У сучасному світі домінуючою стає освіта дорослих під гаслом «Освіта ніколи не закінчується», яке повинно стати пріоритетним не лише у світі, а й в Україні. У кінцевому рахунку, освіта дорослих виявляється провідним фактором забезпечення національної безпеки в умовах глобалізаційних процесів у світі. Освіта дорослих сьогодні $є$ не тільки правом кожного, а й стає одним із ключів, які відкривають двері до життя у XXI ст. та входження до єдиного освітнього та світового простору.

Успішний розвиток економіки, суспільства, кожної людини має супроводжуватися процесом безперервної освіти - навчання «завдовжки в життя» (lifelong learning). Головна ідея нового підходу полягає в тому, що безперервна освіта перестає бути лише одним із аспектів освіти i 
перепідготовки, вона стає основним принципом освітньої системи і участі в ній людини протягом усього безперервного процесу іiі навчальної діяльності [4].

На міжнародній арені одним із основних суб'єктів організації освіти дорослих є всесвітня організація ЮНЕСКО (UNESCO - United Nations Educational, Scientific and Cultural Organization), яка створена як організація для запобігання війни і є єдиною міжнародною організацією 3 питань освіти, в якій бере участь вся міжнародна спільнота Варто зауважити, що XXI століття оголошено ЮНЕСКО «Століттям освіти» [1].

Починаючи з моменту створення в 1945 році, діяльність Організації спрямована на поліпшення стану справ у сфері освіти в усьому світі за допомогою розробки міжнародних норм, надання технічних консультацій $\mathrm{i}$ створення дієздатної організаційної мережі. Діяльність ЮНЕСКО в галузі освіти покликана дати освіту всім, на всіх рівнях і впродовж усього життя, оскільки освіта відіграє головну роль в становленні і розвитку особистості людини і зміцненні ії соціальних зв'язків [1]. Державам-членам ЮНЕСКО рекомендує розглядати освіту дорослих як загальну справу, сприяючи встановленню нового міжнародного порядку, з яким ЮНЕСКО пов'язала себе зобов'язаннями виступати в якості «рупора» світової спільноти 3 наукових, освітніх і культурних питаннях.

Загальним питанням освіти дорослих займались вчені з різних країн, зокрема свої праці означеному питанню присвятили Т. Андрющенко, С. Архипова, С. Болтівець, С. Гончаренко, Т. Десятов, І. Зязюн, Л. Лук'янова, Н. Мукан, Н. Ничкало, І. Носаченко, О. Отич, Л. Пуховська, О. Сєргєєва, С. Сисоєва, Л. Сігаєва, А. Старєва, О. Титаренко. Серед зарубіжних науковців проблему навчання дорослих досліджували С. Вершловський, С. Змєйов, С. Огарьов, В. Онушкін, В. Подобєд, а також П. де Броукер (P. de Broucker), П. Джарвіс (P. Jarvis), Дж. Кідд (J. Kidd), К. Kросс (K. Cross), Дж. Майлс (J. Myles), К. Маєрс (K. Myers), К. Рубенсон (K. Rubenson), Дж. Хекман (J. Heckman) та інші.

Поряд 3 цим, у науковій літературі немає цілісного узагальнення особливостей реалізації Україною міжнародних програм ЮНЕСКО у галузі освіти дорослих.

3 огляду на це, метою статті є вивчання міжнародних нормативноправових актів ЮНЕСКО щодо освіти дорослих та визначення можливостей їх реалізації в Україні.

Дослідження спирається на аналіз та вивчення офіційних нормативноправових актів, документів, доповідей та звітів ООН і ЮНЕСКО, зокрема The Lifelong Learning Programme: education and training opportunities for all, 2011 (Програма навчання впродовж життя: освіта та навчання для всіх, 2011), The Hamburg declaration, 1997 (Гамбурзька декларація, 1997), The world of Education Today and Tomorrow, 1972 (Світова освіта сьогодні та 
завтра, 1972), The Sustainable Development Goals Report, 2017 (Звіт про цілі сталого розвитку, 2017), Programme and budget Unesko 2016-2017 (Програма та бюджет ЮНЕСКО 2016-2017). Також проаналізовано нормативно-правові акти, документи, офіційні звіти України: Конституція України (1996), Закон України «Про освіту» (2017), Бюлетені Національної комісії України у справах ЮНЕСКО (2017), Проект Положення про післядипломну освіту у сфері вищої освіти України (2015).

Аналіз та узагальнення науково-педагогічних матеріалів свідчить про те, що Україна є членом ЮНЕСКО з 12 травня 1954 року. Ї̈̈ членство в ЮНЕСКО стратегічно орієнтоване на сприяння розширенню міжнародного співробітництва наукових, освітніх і культурних інституцій шляхом забезпечення їх участі у програмній діяльності Організації [17].

Метою співробітництва України 3 ЮНЕСКО $є$ зміцнення інтелектуального потенціалу країни та залучення його до загальносвітових процесів в гуманітарній сфері, а також використання в національних інтересах можливостей і ресурсів ЮНЕСКО та міжнародного досвіду співпраці у галузях компетенції цієї Організації - освіти, науки, культури, інформації та комунікації [17].

На сьогодні Україна $є$ учасницею таких міжнародних конвенцій ЮНЕСКО у галузі освіти, як: Конвенція про боротьбу з дискримінацією в галузі освіти (1960), Конвенція про визнання навчальних курсів, дипломів про вищу освіту та вчених ступенів у державах регіону Свропи (1979), Конвенція про визнання кваліфікацій з вищої освіти в європейському регіоні (1997).

Вивчення та узагальнення науково-педагогічних матеріалів свідчить, що в 1976 р. у м. Найробі Генеральна конференція Організації Об'єднаних Націй $з$ питань освіти, науки і культури прийняла «Рекомендації про розвиток освіти дорослих». Установлено, що Україна урахувала рекомендації щодо освіти дорослих та донині спирається на них. Зокрема, в Україні дорослі люди мають вільний доступ до освіти, держава усіляко сприяє популяризації ідеї освіти впродовж життя, реалізації цього права для усіх громадян, та доступу усього дорослого населення країни до участі у політичному і культурному житті.

Ураховуючи прийняті у 1976 р. рекомендації, розвиток освіти дорослих в Україні відбувається в контексті безперервної освіти, необхідної для забезпечення більш раціонального і більш справедливого розподілу ресурсів у галузі освіти між молоддю і дорослими, а також між різними соціальними групами 3 метою забезпечення кращого взаєморозуміння і більш ефективної співпраці між поколіннями.

Як наслідок, освіта дорослих сьогодні стає невід'ємною складовою безперервної освіти, сприяє економічному і культурному розвитку країни, iii соціальному прогресу. 
Доцільно звернути увагу на те, що у рамках Рекомендацій 1976 року також було визначено принципи, на яких і базується освіта дорослих в сучасній Україні. Зокрема серед них варто назвати такі:

- освіта грунтується на потребах людей i використовує їх різнобічний досвід;

- освіта дорослих сприяє реалізації можливості і прагнення всіх людей розвиватися протягом всього життя як в особистому плані, так і в плані соціальної діяльності;

- освіта дорослих стимулює і підтримує інтерес дорослих, віру в себе і забезпечує їх активну участь на всіх етапах процесу освіти, до якої вони залучені;

- освіта дорослих пристосована до конкретних умов побуту і праці, враховує особисті якості дорослих учнів, їх вік, сімейний, соціальний, професійний статус, середовище, в якому вони живуть, і характер взаємозв'язку цих факторів;

- освіта дорослих організовується і здійснюється досить гнучко 3 урахуванням соціальних, культурних, економічних i інституційних чинників країни та суспільства, до якого належать дорослі учні;

- освіта дорослих сприяє економічному та соціальному розвитку українського суспільства в цілому;

- освіта дорослих визнає, що кожен дорослий, чоловік або жінка, в силу свого життєвого досвіду, є носієм культури, що дає йому можливість виступати в процесі освіти, в якому він бере участь, одночасно в якості того, хто навчається і того, хто навчає $[11 ; 13]$.

Варто також зауважити, що 3 метою розвитку питань освіти дорослих один раз на 12 років проводиться Міжнародна конференція ЮНЕСКО. Перша Конференція відбулася в Ельсінорі (Данія) в 1949 р., наступні конференції проводилися: в Монреалі (Канада, 1960 р.), у Токіо (Японія, 1972 р.), в Парижі (Франція, 1985 р.), в Гамбурзі (Німеччина, 1997 р.), у Белені (Бразилія, 2009 р.). Міжнародні конференції ЮНЕСКО 3 питань освіти дорослих (CONFINTEA) $є$ важливою платформою на міжнародному рівні для політичного діалогу i прийняття нових зобов'язань в галузі освіти дорослих. Вони є також одним із найбільш визнаних форумів, очолюваних ЮНЕСКО.

Так, Конференція в Німеччині (CONFINTEA V, 1997 р.) стала визначною подією в історії міжнародного визнання важливості навчання i освіти дорослих, сприяла прийняттю ряду зобов'язань та нормативноправових актів у цій сфері. У п'ятій Конференції ЮНЕСКО з питань освіти дорослих брали участь делегати зі 140 країн світу, в тому числі керівництво ООН, ЮНЕСКО, міністри освіти, культури та інформації різних країн світу. На конференції освіту дорослих було проголошено 
одним із унікальних способів стійкого розвитку суспільства. Увагу світової громадськості було зосереджено на тому, що навчання і освіта дорослих $\epsilon$ необхідною складовою частиною освіти впродовж усього життя [5].

На вищезазначеній Міжнародній конференції ЮНЕСКО з питань освіти дорослих була прийнята «Гамбурзька декларація про навчання дорослих». Учасники Конференції, як наголошує Л. Сігаєва, підтвердили, що освіта дорослих включає весь комплекс формального чи іншого навчання, за допомогою якого люди, які є з точки зору суспільства, до якого вони належать, дорослими, розвивають свої здібності, збагачують свої знання і удосконалюють технічні та професійні кваліфікації або ж застосовують їх у новому напрямі для задоволення своїх потреб і потреб свого суспільства [16].

Україна прийняла та підтримала всі положення Гамбурзької декларації, що мало позитивний вплив на різні аспекти організації освіти дорослих, зокрема на становлення та реформування нормативнозаконодавчої бази, на активний процес створення ефективних мереж у межах формальних i неформальних систем, а також нововведень i застосування більш творчого і гнучкого підходу до освіти дорослих, сприяла переосмисленню підходів до методик організації навчання дорослих.

Сьогодні в Україні згідно 3 Гамбурзькою декларацією навчання дійсно відбувається протягом усього життя. Разом із тим українськими педагогами та науковцями розробляються і здійснюються соціальні програми підтримки тієї частини дорослого населення, яка прагне брати участь в освітній діяльності. Відповідно до вимог та рішень ЮНЕСКО українська держава гарантує кожній дорослій людині право на навчання, форму якого людина обирає сама $[11 ; 12]$.

Аналіз науково-педагогічної літератури та нормативних матеріалів свідчить, що Шоста Міжнародна конференція в Бразилії (CONFINTEA VI, 2009 р.) надала імпульс до вивчення шляхів і засобів для вирішення найбільш важливих питань і проблем у галузі освіти дорослих. Такими проблемами на міжнародному рівні були визнані: питання поширення грамотності серед дорослих, базова i безперервна освіта дорослих i навчання протягом усього життя, які повинні стати ключовими засобами для вирішення глобальних проблем у таких сферах, як: демократія, мир і права людини, збереження різноманітності, освіта для всіх, освіта в інтересах сталого розвитку, врегулювання конфліктів і розвиток трудових ресурсів.

Згідно з результатами діяльності ЮНЕСКО та ії освітніх ініціатив, освіта в Україні вважається однією 3 найважливіших цілей сталого розвитку, від якої великою мірою залежить успіх у досягненні інших 16-ти цілей, проголошених ООН. Відповідно до цієї цілі в Україні було 
сформовано програму сталого розвитку в освіті, метою якої є забезпечення всебічної та доступної якісної освіти, а також створення можливостей навчання людей протягом усього життя. Зазначена програма базується на положеннях ухваленої у листопаді 2015 р. Рамкової програми дій $\mathrm{OOH}$ «Освіта 2030», якою визначено загальний механізм реалізації цілей сталого розвитку.

Варто зазначити, що ЮНЕСКО розробила і кафедральну програму, призначену для розвитку університетської мережі та інших шляхів співробітництва вищих навчальних закладів на міжрегіональному, регіональному та субрегіональному рівнях. Кафедри ЮНЕСКО створені і об'єднані в університетську мережу UNITWIN Networks. Програма університетських кафедр ЮНЕСКО (UNITWIN - university twining and networking) є головним засобом для обміну, трансферу нових знань у взаємодії з багатьма вищими навчальними закладами, $\epsilon$, як правило, міждисциплінарними, сприяють інтеграції освіти, науки, культурного різноманіття. За допомогою кафедр ЮНЕСКО надається всебічна підтримка міжнародного співробітництва в галузі вищої освіти [8].

У рамках цієї кафедральної програми в провідних вищих навчальних закладах України створено та діють 13 кафедр програми ЮНЕСКО/ UNITWIN, що відкриває можливості для міжнародної наукової співпраці у різних напрямах. Серед них - лінгвістика, філософія людського спілкування, застосування інформаційних та комунікаційних технологій в освіті, превентивна освіти та соціальна політика, екологія техногенних регіонів, кріобіологія, клітинна і молекулярна нейробіологія, права людини і демократія [18].

Ще однією вагомою ініціативою ЮНЕСКО у сфері освіти дорослих стало впровадження Програми Grundtvig 3 метою надання можливостей для отримання якісної освіти для дорослих на основі Свропейської співпраці. Це: підтримка транснаціональних проектів, створення нових партнерств та мереж, розвиток мобільності вчителів і викладачів. Програма Grundtvig є частиною програми Європейської Комісії «Освіта впродовж життя» на 2007-2013 роки [6] та спрямована на зміцнення європейського виміру освіти дорослих та навчання протягом усього життя в Свропі.

В Україні Програма Grundtvig була спеціально спрямована на вирішення освітніх завдань дорослого населення та надання йому альтернативних шляхів вдосконалення їх навичок та компетенцій. Програма Grundtvig охоплює всі види навчання, незалежно від того, відбуваються вони у формальних, неформальних чи інформальних системах навчання для дорослих, таких як автономне навчання, навчання в громаді або навчання на основі власного досвіду. Програма Grundtvig надає фінансування для широкого кола заходів, зокрема вивчення 
іноземних мов, організація батьківської освіти, створення проектів у галузі мистецтва та культури тощо. Всі проекти передбачають співпрацю 3 європейськими партнерами та пропонують досвід навчання й особистого розвитку для співробітників та студентів.

Європейська комісія також анонсувала створення Інтегрованої програми нового покоління, яка включає в себе проекти Comenius, Erasmus, Leonardo da Vinci, Grundtvig, Jean Monnet. Основними завданнями зазначеної програми мають стати: підвищення якості та ефективності освіти в Європі; вдосконалення підготовки педагогів; розвиток нових умінь i компетенцій; забезпечення доступності IKT; підвищення ефективності інвестицій в освіту та доступності освіти всіх рівнів протягом усього життя.

Зауважимо, що в Україні існують певні труднощі в реалізації освітніх програм ЮНЕСКО для дорослих. Серед них можна виділити: низьку поінформованість дорослих людей щодо можливості участі в освітніх програмах, стереотипні побоювання щодо навчання у дорослому віці, низький рівень фінансування освітніх проектів, відсутність спеціального законодавства у галузі освіти дорослих тощо.

Але, незважаючи на означені труднощі, для української практики організації освіти дорослих характерні наступні тенденції: безперервність; збільшення кількості людей, задіяних у сфері освітніх послуг; широке охоплення фахівців, що підвищують свою кваліфікацію або прагнуть змінити професію; значимість якості освіти; орієнтація на саморозвиток, самореалізацію дорослих людей в освітній діяльності. Так, на 39-тій сесії Генеральної конференції ЮНЕСКО (2017р.) представник України наголосив, що Україна готова підтримувати реформи ЮНЕСКО та продовжувати брати активну участь у всіх сферах ії діяльності [9].

Як свідчить проведене дослідження, Україна активно впроваджує рекомендації ЮНЕСКО щодо освіти дорослого населення, бере активну участь у роботі Організації, сприяє реалізації освітніх проектів як в Україні, так і за іï межами. Зокрема, на розвиток освіти дорослих та організацію безперервної освіти в Україні значний вплив мали Міжнародні конференції, Програма університетських кафедр ЮНЕСКО (UNITWIN), Програма Grundtvig. Зазначені заходи сприяли розробці та становленню нормативно-правової бази України щодо освіти дорослих, розширенню мережі навчальних закладів для дорослих, популяризації неформальної та інформальної освіти, розробці принципів, форм та методів сучасної освіти дорослого населення.

Серед перспектив подальших досліджень варто виділити проведення порівняльно-педагогічного аналізу діяльності українських та європейських освітніх закладів для дорослого населення, визначити можливості їхнього співробітництва та обміну цінним педагогічним досвідом. 


\section{СПИСОК ВИКОРИСТАНИХ ДЖЕРЕЛ}

1. Introducing UNESCO: what we are. Retrieved from. URL : http://www. unesco.org/new/en/unesco/about-us/who-we-are/introducing-unesco/

2. Learning to be. The world of Education Today and Tomorrow. - P. : Unesko; L. : Harrap, 1972. - 346 p.

3. Programme and budget 2016-2017. Second biennium of the 2014-2017 quadrennium. - P. : Unesko, 2016. -345 p.

4. The Encyclopedia of Informal Education / Non-Formal Education. Retrieved from. URL : http://www.infed.org/biblio/b-nonfor.htm

5. The Hamburg declaration. The agenda for the future. - Hamburg, 1997. $30 \mathrm{p}$.

6. The Lifelong Learning Programme: education and training opportunities for all. Retrieved from: URL : https://web.archive.org/web/20130302074306/ http://ec.europa.eu/education/lifelong-learning-programme/doc78_en.htm

7. The Sustainable Development Goals Report (2017). United Nations New York.

8. Бюлетень Національної комісії України у справах ЮНЕСКО. - Київ, 2017. - № 7. $-11 \mathrm{p}$.

9. Бюлетень Національної комісії України у справах ЮНЕСКО. - Київ, 2017. - № 8. $-11 \mathrm{p}$.

10. Глосарій Європейського простору вищої освіти. - Одеса : Ранок, 2001. $-232 \mathrm{c}$.

11. Закон України «Про освіту» [Електронний ресурс]. URL : http://zakon2.rada.gov.ua/laws/show/2145-19/page

12. Конституція України. [Електронний ресурс]. URL : http://zakon2.rada. gov.ua/laws/show $/ 254 \% \mathrm{D} 0 \% \mathrm{BA} / 96-\% \mathrm{D} 0 \% \mathrm{~B} 2 \% \mathrm{D} 1 \% 80$

13. Концепція освіти дорослих в Україні / укл.: Лук'янова Л. Б. - Ніжин : ПП Лисенко М. М., 2011. - 24 с.

14. Освіта дорослих : енциклопед. слов. / Нац. акад. пед. наук України, Нац. акад. держ. упр. при Президентові України [та ін.] ; за ред. В. Г. Кременя, Ю. В. Ковбасюка. - Київ : Основа, 2014. - 491 с.

15. Проект положення про післядипломну освіту у сфері вищої освіти в Україні [Електронний ресурс]. URL : http://old.mon.gov.ua/ua/prviddil/1312/1421144886/1428566485/

16. Сігаєва Л. Міжнародне співробітництво у сфері освіти дорослих / Л. Сігаєва // Порівняльна професійна педагогіка. - 2012. - № 1. C. $14-23$.

17. Співробітництво України та ЮНЕСКО [Електронний ресурс]. URL : http://unesco.mfa.gov.ua/ua/ukraine-unesco/cooperation

18. Участь України у діалозі ЮНЕСКО [Електронний ресурс]. URL : http://mfa.gov.ua/ua/page/open/id/639 